\title{
Monitoring of the Deposition of PAHs and Metals Produced by a Steel Plant in Taranto (Italy)
}

\author{
M. Amodio, ${ }^{1}$ G. de Gennaro, ${ }^{2,3}$ A. Di Gilio, ${ }^{2}$ and M. Tutino ${ }^{2}$ \\ ${ }^{1}$ LEnviroS Srl, Spin-Off of University of Bari “Aldo Moro", Via Orabona 4, 70126 Bari, Italy \\ ${ }^{2}$ Apulia Regions Environmental Protection Agency (ARPA Puglia), Corso Trieste 27, 70126 Bari, Italy \\ ${ }^{3}$ Chemistry Department, University of Bari "Aldo Moro", Via Orabona 4, 70125 Bari, Italy \\ Correspondence should be addressed to M. Tutino; m.tutino@arpa.puglia.it
}

Received 7 March 2014; Accepted 22 July 2014; Published 28 August 2014

Academic Editor: Julio Diaz

Copyright (C) 2014 M. Amodio et al. This is an open access article distributed under the Creative Commons Attribution License, which permits unrestricted use, distribution, and reproduction in any medium, provided the original work is properly cited.

\begin{abstract}
A high time-resolved monitoring campaign of bulk deposition of PAHs and metals was conducted near the industrial area and at an urban background site in province of Taranto (Italy) in order to evaluate the impact of the biggest European steel plant. The deposition fluxes of the sum of detected PAHs at the industrial area ranged from 92 to $2432 \mathrm{ng} \mathrm{m}^{-2} \mathrm{~d}^{-1}$. In particular the deposition fluxes of $\mathrm{BaP}, \mathrm{BaA}$, and $\mathrm{BkF}$ were, on average, 10,14, and 8 times higher than those detected at the urban background site, respectively. The same finding was for metals. The deposition fluxes of $\mathrm{Ni}\left(19.8 \mu \mathrm{g} \mathrm{m}^{-2} \mathrm{~d}^{-1}\right)$ and As $\left(2.2 \mu \mathrm{g} \mathrm{m}^{-2} \mathrm{~d}^{-1}\right)$ at the industrial site were about 5 times higher than those at the urban background site, while the deposition fluxes of Fe $\left(57 \mathrm{mg} \mathrm{m}^{-2} \mathrm{~d}^{-1}\right)$ and Mn $\left(1.02 \mathrm{mg} \mathrm{m}^{-2} \mathrm{~d}^{-1}\right)$ about 31 times higher. Precipitation and wind speed played an important role in PAH deposition fluxes. Fe and Mn fluxes at the industrial site resulted high when wind direction favored the transport of air masses from the steel plant to the receptor site. The impact of the industrial area was also confirmed by IP/(IP + BgP), IP/BgP, and BaP/BgP diagnostic ratios.
\end{abstract}

\section{Introduction}

Atmospheric deposition has been identified as an important source of pollutants for terrestrial and aquatic environments, especially near urban and industrial areas, where a great amount of particulate polycyclic aromatic hydrocarbon (PAHs) and metal concentrations are emitted [1-3]. These pollutants can be transported far from their sources and they may reach very remote environments. PAHs are produced as byproducts of the incomplete combustion of fossil fuels or pyrolysis of organic materials, while metals are emitted in gaseous form from combustion processes, adsorbed on fine particles, and retained in heavier ash [4-8]. The growing interest in these pollutants is due to their toxicity for human health [9-14]. Iron and steel industries are known to be hot spots of organic micropollutants, such as PAHs, and heavy metals. Steel is mainly produced in integrated works using a series of closely linked phases: coke ovens, sintering, blast furnace, basic oxygen steelmaking, and finishing procedures. Among these processes, coke ovens and sinter plants have been identified as potential sources of metals and PAHs. Therefore, air pollution has become a serious problem for highly industrialized areas such as Taranto (Apulia region, Italy). Taranto is one of the areas identified at high risk of environmental crisis in Italy and it has been included in the list of the polluted sites of national interest (SIN) because of a wide industrial area developed close to the urban settlement, having a high population density $[15,16]$. Although several studies were carried out in the last decade in order to evaluate pollutant concentrations in atmosphere [17-21], no study was performed to evaluate deposition fluxes of PAHs and metals near the steel plants of Taranto. Therefore, this work aims to present the first and high time-resolved study on atmospheric deposition fluxes and chemical imprints near the biggest steel plant in Europe. To this end, monitoring campaigns of bulk deposition were conducted near the industrial area and at an urban background site in the province of Taranto (South of Italy). In particular, sampling periods of a week at the most critical site and two weeks in the urban background site were performed. PAHs and some metals were analyzed, and 
deposition fluxes were quantified. The comparison between the two sampling sites and the effect of meteorological parameters (rainfall and wind speed and direction) on the deposition fluxes of PAHs and metals were investigated.

\section{Material and Methods}

2.1. Sampling Sites. Bulk deposition samples were collected at an industrial site of Taranto (South of Italy) and at an urban background site of Mottola, a city of Taranto province (see Figure 1). Taranto $\left(40^{\circ} 28^{\prime} \mathrm{N} 17^{\circ} 14^{\prime} \mathrm{E}\right)$ is the third most populated city of Southern Italy and it is the seat of one of the biggest steel plants in Europe. Moreover, in Taranto, there is an important industrial area in which metallurgical, chemical, petrochemical, and cement-producing plants, military and trade harbor, and naval shipbuilding industry are located. The industrial site (Taranto) was located near the iron and steel pole of Taranto (Figure 1). Mottola $\left(40^{\circ} 38^{\prime} 0^{\prime \prime} \mathrm{N}\right.$, $\left.17^{\circ} 02^{\prime} 0^{\prime \prime}\right)$ is a small city of about fifteen thousand inhabitants, situated on a hill ( 370 meters on sea levels) in the subregion of Murgia. The monitoring site (Mottola) was located in a suburban area of the city but close to a busy regional highway, so it can be classified as urban background site (Figure 1).

2.2. Sampling. Bulk deposition samples were collected from October 16, 2007, to February 13, 2008, with sampling periods of 7 and 15 days each month at industrial and urban background sites, respectively. A total of 16 samples at the industrial site and 8 samples at the urban background site were collected over the investigated period. Bulk particle deposition (wet + dry depositions) collections were achieved using two bulk collectors consisting of a funnel-bottle combination openly exposed at all times (LabService Analytica Srl, Italy). Collectors were made in glass for PAHs and high density polyethylene for metals. They have an aperture of $800 \mathrm{~cm}^{2}$ placed at 1,5 meters above ground in order to avoid the sample contamination due to ground during heavy rains. Prior to the sampling, the inner surface of the funnel was washed according to UNI EN 15980:2011 and UNI EN 15841:2010 [21, 22]. In each site the following meteorological parameters were also monitored: ambient temperature, solar radiation, barometric pressure, rainfall, and wind speed and direction.

2.3. Analysis of Polycyclic Aromatic Hydrocarbons (PAHs). After sampling, the inner surfaces of the funnel were wiped with precleaned cotton and the collected water was filtered through precleaned glass fibre filters $(0.7 \mu \mathrm{m}, 47 \mathrm{~mm}$ i.d, Whatman). The filtrate was liquid-liquid extracted with DCM in accordance with UNI EN 15980:2011. The filter and the wiping material were extracted with a mixture of acetone/hexane by means of microwave assisted solvent extraction $[17,23]$. PAH extraction was realized using Milestone, model Ethos D (Milestone s.r.l., Sorisole (BG), Italy). The extracted samples were individually analysed using an Agilent 6890 PLUS gas chromatograph (Agilent Technologies, Inc., Santa Clara, CA, USA) equipped with

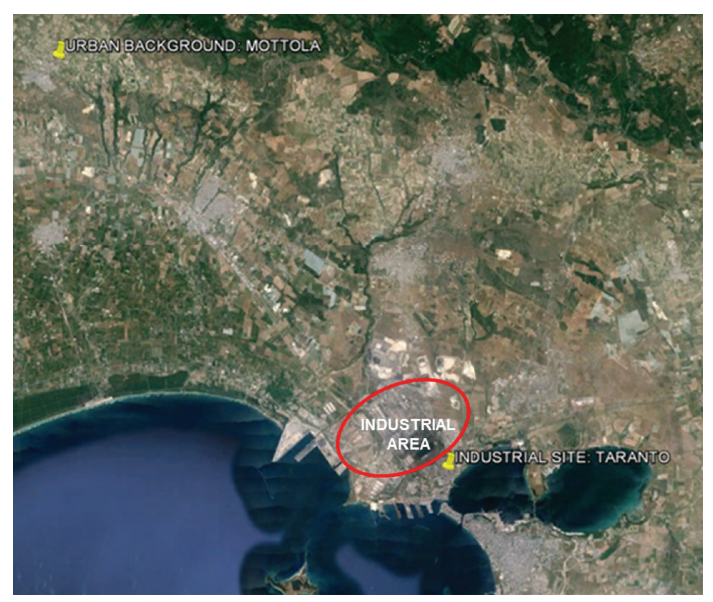

FIGURE 1: Map of the investigated area.

a programmable temperature vaporization injection system (PTV) and interfaced to a mass spectrometer, operating in electron impact ionization (Agilent MS-5973 N) [19]. In this work, benzo[a]anthracene $(\mathrm{BaA})$, benzo[b+j]fluoranthene $(\mathrm{BbF})$, benzo[k]fluoranthene $(\mathrm{BkF})$, benzo[a]pyrene $(\mathrm{BaP})$, indeno[1,2,3-cd]pyrene (Ip), benzo[ghi]perylene (BgP), and dibenzo[a,h] anthracene (DBA) were analysed as they represent harmful substances for human health [24]. The quantitative determination was carried out using the signals corresponding to the molecular ions of PAHs: BaA (228), BbF (252), BkF (252), BaP (252), Ip (276), BgP (276), and DbA (278). Perylene-D12 (PrD, 264) was used as internal standard (I.S.). The analytical performances (extraction recovery, extraction linearity, analytical repeatability, and LOD) were verified in our previous work [23].

2.4. Analysis of Metals. The sample was acidified on arrival at the laboratory by adding $1 \mathrm{~mL}$ of concentrated nitric acid per $100 \mathrm{~mL}$ sample to dissolve the metals bound to particles or adsorbed to the walls of the container and to prevent growth of microorganisms [22]. The whole acidified sample was vacuum filtered and the filter (cellulose acetate; pore size $0.45 \mu \mathrm{m}$ ) was digested in $8 \mathrm{~mL}$ of nitric acid and $2 \mathrm{~mL}$ of hydrogen peroxide solution by using a microwave system (Milestone model Ethos D) [22]. The extract was analysed by inductively coupled plasma-mass spectrometry (ICP-MS, Perkin Elmer ELAN 9000). Acidified filtrates were individually analysed by ICP-MS [22]. The concentrations of Fe and $\mathrm{Mn}$ in bulk deposition were determined as micrograms per square metre day and $\mathrm{Cd}, \mathrm{As}$, and $\mathrm{Ni}$ as nanograms per square metre day.

2.5. Data Treatment. Pearson correlation analysis was applied to collected data. Pearson's correlation coefficient (Pearson's $r$ ) is a measure of the linear correlation between two variables, giving a value between +1 and -1 . Total positive or negative correlation occurred between two variables when $r$ is equal to 1 or -1 , respectively. There is no correlation between variables when $r$ is equal to 0 . 


\section{Results and Discussion}

Bulk deposition fluxes of PAHs and metals obtained during the monitoring campaign at the industrial and urban sites are listed in Tables 1-4. The deposition fluxes of the sum of investigated PAHs ( $\sum$ PAHs) at the industrial area ranged from 92 to $2432 \mathrm{ng} \mathrm{m}^{-2} \mathrm{~d}^{-1}$ with an average flux of $1012 \mathrm{ng} \mathrm{m}^{-2} \mathrm{~d}^{-1}$. Moreover, it was found that the daily mean flux of $\mathrm{BaP}$ was $148 \mathrm{ng} \mathrm{m}^{-2} \mathrm{~d}^{-1}$ with a range from 11 to $303 \mathrm{ng} \mathrm{m}^{-2} \mathrm{~d}^{-1}$. BaP fluxes are comparable to those reported by Esen et al. in an industrial site of Turkey or monitored during the winter in China $\left(220 \mathrm{ng} \mathrm{m}^{-2} \mathrm{~d}^{-1}\right)[25,26]$. Pearson correlation analysis was also applied to data set showing that individual PAHs were strongly correlated with each other (Pearson's $r$ in the range: 0.75-0.99) with the exception of $\mathrm{BaP}$ for which lower correlation was found (Pearson's $r$ in the range: $0.49-0.76$ ). This finding is not in line with the results reported in our previous work which focused on particulate $\mathrm{PAH}$ concentrations monitored in the same industrial area [17]. However Li et al. (2009) showed that deposition fluxes of PAHs were not correlated with particulate PAHs in air because they were affected by different factors during the several seasons [27]. This change can be attributed to the different distribution patterns of PAHs among the several particle size fractions, different precipitation scavenging ratios, and deposition velocities of different size particles. Moreover the different reactivity of PAHs in atmospheric processes period should be also considered [27]. Various studies demonstrated that $\mathrm{BaP}$ degrades photolytically in the atmosphere at much faster rates than its isomers or other commonly measured parent PAHs [28, 29]. In highly polluted areas, as the industrial area of Taranto, the high concentrations of pollutants such as ozone and/or oxides of nitrogen promote $\mathrm{BaP}$ degradation.

Lower PAH deposition fluxes were detected at urban background site of Mottola: average flux over the monitoring period was $211 \mathrm{ng} \mathrm{m}^{-2} \mathrm{~d}^{-1}$ which ranged between 87 and $476 \mathrm{ng} \mathrm{m}^{-2} \mathrm{~d}^{-1}$. This site was characterized by daily mean $\mathrm{BaP}$ flux of $17 \mathrm{ng} \mathrm{m}^{-2} \mathrm{~d}^{-1}\left(7-38 \mathrm{ng} \mathrm{m}^{-2} \mathrm{~d}^{-1}\right)$ as in Venice Lagoon site (Italy) $\left(33.7 \mathrm{ng} \mathrm{m}^{-2} \mathrm{~d}^{-1}\right)$ [30]. As shown in Table 2, the highest deposition fluxes were determined for $\mathrm{BgP}$ confirming Mottola site as urban one [31,32]. Moreover, significant positive correlations were found among investigated PAHs (average Pearson's $r=0.88$ ) and also for BaP (Pearson's $r$ in the range 0.76.-0.99). Bulk deposition fluxes of the sum of PAHs ( $(\mathrm{PAHs})$ measured at industrial site were averaged over a period of 15 days in order to compare the two monitored sites (see Figure 2). Deposition fluxes of $\sum$ PAHs near the industrial area of Taranto were on average six times higher than those at the urban background site with peak values 10 times higher during the first four monitored periods. About single PAH, it was found that deposition fluxes of $\mathrm{BaP}, \mathrm{BaA}$, and $\mathrm{BkF}$ at industrial site were on average substantially 10,14 , and 8 times higher than those detected in urban background site, respectively. Lower enrichments (4-6 times) were determined for other investigated PAHs.

Average deposition fluxes of $\mathrm{Fe}, \mathrm{Mn}, \mathrm{Ni}, \mathrm{As}$, and $\mathrm{Cd}$ at the industrial and the urban background sites are shown

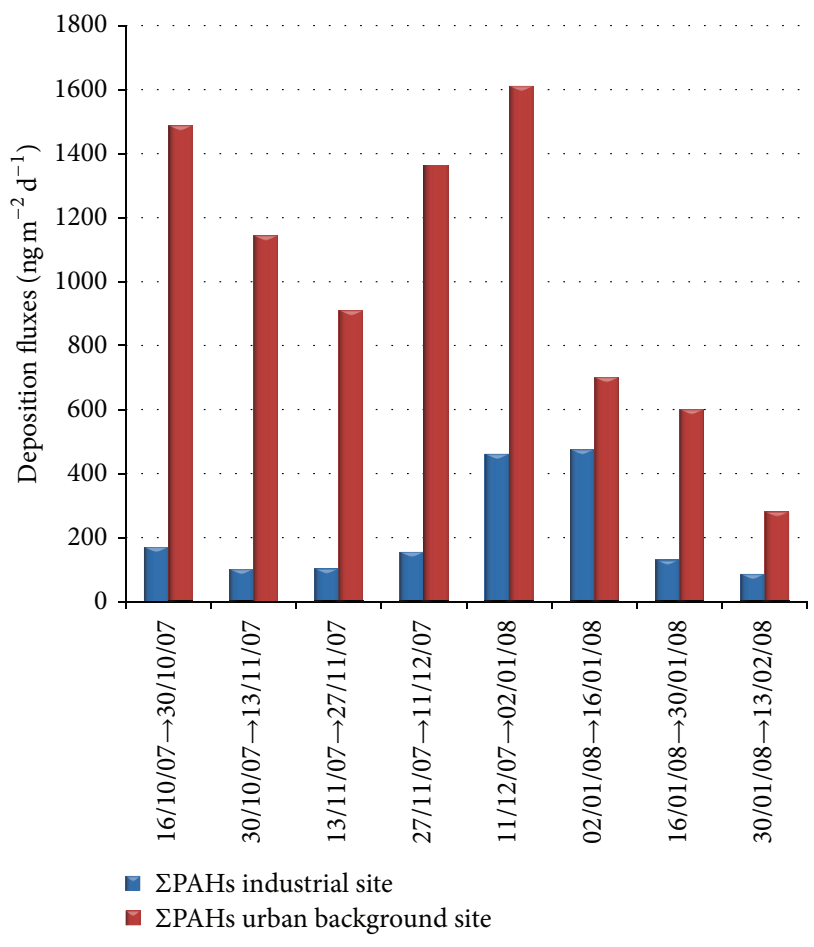

Figure 2: Sum of the PAHs detected ( $\sum$ PAHs) in $\mathrm{ng} \mathrm{m}^{-2} \mathrm{~d}^{-1}$ at two monitored sites.

in Tables 3 and 4. The deposition fluxes of metals near the industrial area were higher than those determined at the urban background site for all sampling periods, except for Cd. Several studies on elemental composition of PM demonstrated that $\mathrm{Cd}$ can be considered as a traffic marker because it is emitted by the wearing of tyres, brakes, and other parts of vehicles [33-35]. In particular, the deposition fluxes of $\mathrm{Ni}$ and As at industrial site were about 5 times higher than those determined at the urban background site, while the deposition fluxes of $\mathrm{Fe}$ and $\mathrm{Mn}$ were 31 times higher. For example, the comparison between Fe deposition fluxes at two monitored sites is reported in Figure 3. Ni and As deposition fluxes at industrial site (19.8 and $2.2 \mu \mathrm{g} \mathrm{m}^{-2} \mathrm{~d}^{-1}$ on average, resp.) were similar to those determined at other coastal sites in Tokyo, France, and China and at industrial site in Spain [36-39]. The mean deposition fluxes for $\mathrm{Ni}$ and As at urban background site (3.7 and $0.5 \mu \mathrm{g} \mathrm{m}^{-2} \mathrm{~d}^{-1}$, resp.) were similar to those determined in USA by Sweet et al. [40]. Manganese at the industrial site $\left(1.02 \mathrm{mg} \mathrm{m}^{-2} \mathrm{~d}^{-1}\right.$ on average) resulted higher than that determined in many polluted countries such as in China [38]. Nowadays no information is available on Fe concentrations in bulk deposition fluxes at the industrial and the urban sites and even less at the industrial area of Taranto that was identified as an area of high environmental risk in Italy. Therefore the high-time resolved information on Fe bulk deposition obtained by this study $\left(57 \mathrm{mg} \mathrm{m}^{-2} \mathrm{~d}^{-1}\right.$ on average) is of great interest to the scientific community and stakeholders. In particular it was found that Fe fluxes were two orders of magnitude higher than those determined only in dry deposition in USA and five times higher than those 


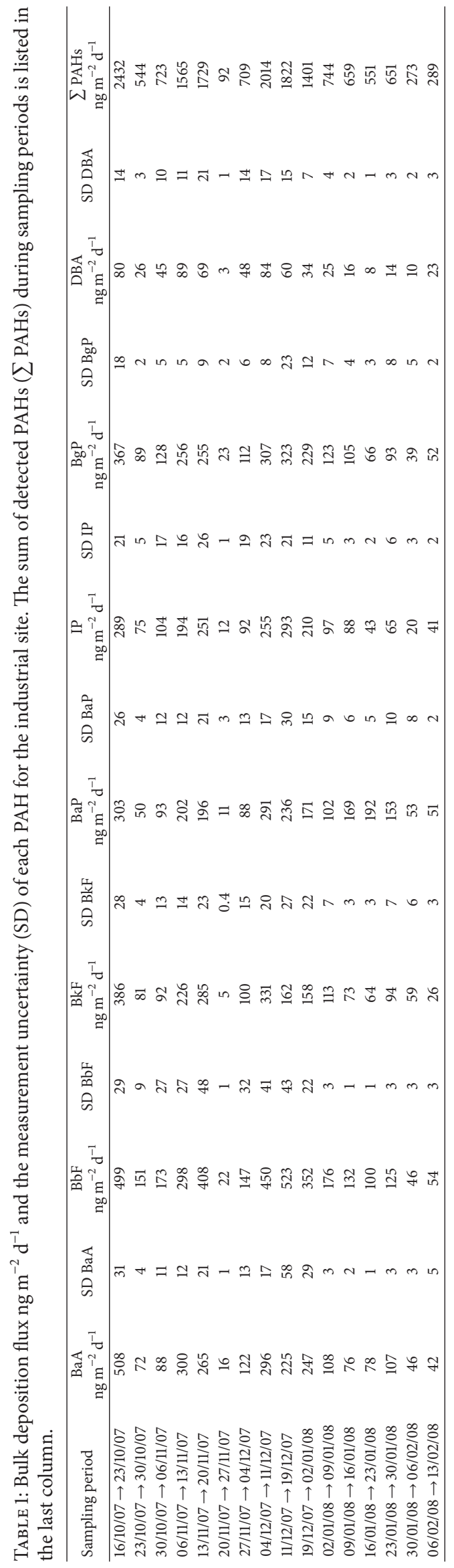




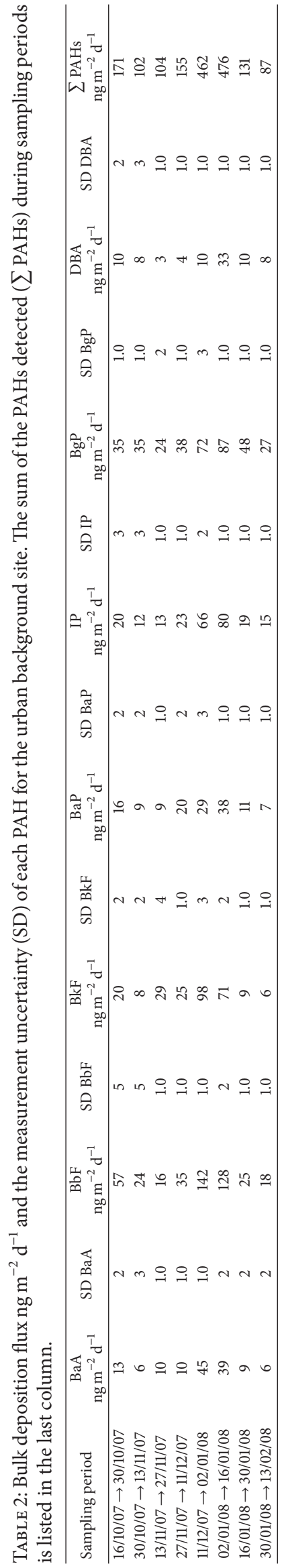


TABLE 3: Bulk deposition flux and the measurement uncertainty (SD) of Fe and $\mathrm{Mn} \mu \mathrm{g} \mathrm{m}^{-2} \mathrm{~d}^{-1}$ and of Ni, As, and Cd ng m $\mathrm{m}^{-2}$ for the industrial site.

\begin{tabular}{|c|c|c|c|c|c|c|c|c|c|c|}
\hline Sampling period & $\begin{array}{c}\mathrm{Fe} \\
\mu \mathrm{g} \mathrm{m}^{-2} \mathrm{~d}^{-1}\end{array}$ & $\mathrm{SD} \mathrm{Fe}$ & $\begin{array}{c}\mathrm{Mn} \\
\mu \mathrm{g} \mathrm{m}^{-2} \mathrm{~d}^{-1}\end{array}$ & SD Mn & $\begin{array}{c}\mathrm{Ni} \\
\mathrm{ng} \mathrm{m}^{-2} \mathrm{~d}^{-1}\end{array}$ & SD Ni & $\begin{array}{c}\text { As } \\
\operatorname{ng~m}^{-2} \mathrm{~d}^{-1} \\
\end{array}$ & SD As & $\begin{array}{c}\mathrm{Cd} \\
\operatorname{ng~m}^{-2} \mathrm{~d}^{-1}\end{array}$ & $\mathrm{SD} \mathrm{Cd}$ \\
\hline $16 / 10 / 07 \rightarrow 23 / 10 / 07$ & 94495 & 818 & 1966 & 29 & 42987 & 564 & 2969 & 31 & 872 & 31 \\
\hline $23 / 10 / 07 \rightarrow 30 / 10 / 07$ & 19398 & 406 & 541 & 6 & 10114 & 67 & 1189 & 43 & 391 & 22 \\
\hline $30 / 10 / 07 \rightarrow 06 / 11 / 07$ & 83990 & 409 & 1464 & 18 & 34958 & 393 & 1598 & 48 & 287 & 16 \\
\hline $06 / 11 / 07 \rightarrow 13 / 11 / 07$ & 102358 & 1630 & 2239 & 28 & 50575 & 1003 & 3704 & 47 & 618 & 14 \\
\hline $13 / 11 / 07 \rightarrow 20 / 11 / 07$ & 66651 & 816 & 1155 & 20 & 25823 & 229 & 2186 & 50 & 397 & 34 \\
\hline $20 / 11 / 07 \rightarrow 27 / 11 / 07$ & 4450 & 248 & 107 & 4 & 4111 & 62 & 363 & 18 & 140 & 17 \\
\hline $27 / 11 / 07 \rightarrow 04 / 12 / 07$ & 55716 & 405 & 1055 & 16 & 26769 & 476 & 1862 & 38 & 380 & 46 \\
\hline $04 / 12 / 07 \rightarrow 11 / 12 / 07$ & 86231 & 409 & 2557 & 32 & 36221 & 664 & 3291 & 50 & 608 & 4 \\
\hline $11 / 12 / 07 \rightarrow 19 / 12 / 07$ & 90099 & 1426 & 1856 & 66 & 36382 & 375 & 3314 & 66 & 619 & 26 \\
\hline $19 / 12 / 07 \rightarrow 02 / 01 / 08$ & 46449 & 613 & 1152 & 36 & 19265 & 358 & 2007 & 71 & 358 & 21 \\
\hline $02 / 01 / 08 \rightarrow 09 / 01 / 08$ & 33832 & 410 & 796 & 15 & 12793 & 205 & 1277 & 32 & 258 & 19 \\
\hline 09/01/08 $\rightarrow 16 / 01 / 08$ & 36963 & 815 & 679 & 18 & 12138 & 183 & 5083 & 764 & 535 & 44 \\
\hline $16 / 01 / 08 \rightarrow 23 / 01 / 08$ & 45999 & 1228 & 1144 & 51 & 14279 & 283 & 1432 & 91 & 395 & 15 \\
\hline $23 / 01 / 08 \rightarrow 30 / 01 / 08$ & 106110 & 2558 & 2359 & 96 & 35150 & 508 & 5900 & 188 & 478 & 24 \\
\hline $30 / 01 / 08 \rightarrow 06 / 02 / 08$ & 21899 & 410 & 487 & 10 & 5466 & 255 & 1120 & 24 & 185 & 6 \\
\hline $06 / 02 / 08 \rightarrow 13 / 02 / 08$ & 31665 & 818 & 551 & 9 & 16238 & 718 & 901 & 24 & 246 & 22 \\
\hline
\end{tabular}

TABLE 4: Bulk deposition flux and the measurement uncertainty (SD) of Fe and $\mathrm{Mn} \mu \mathrm{g} \mathrm{m}^{-2} \mathrm{~d}^{-1}$ and of Ni, As, and Cd ng m $\mathrm{m}^{-1}$ with standard deviation for the urban background site.

\begin{tabular}{|c|c|c|c|c|c|c|c|c|c|c|}
\hline Sampling period & $\begin{array}{c}\mathrm{Fe} \\
\mu \mathrm{g} \mathrm{m}^{-2} \mathrm{~d}^{-1}\end{array}$ & $\mathrm{SD} \mathrm{Fe}$ & $\begin{array}{c}\mathrm{Mn} \\
\mu \mathrm{g} \mathrm{m}^{-2} \mathrm{~d}^{-1}\end{array}$ & SD Mn & $\begin{array}{c}\mathrm{Ni} \\
\mathrm{ng} \mathrm{m}^{-2} \mathrm{~d}^{-1}\end{array}$ & $\mathrm{SD} \mathrm{Ni}$ & $\begin{array}{c}\text { As } \\
\mathrm{ng} \mathrm{m}^{-2} \mathrm{~d}^{-1}\end{array}$ & SD As & $\begin{array}{c}\mathrm{Cd} \\
\mathrm{ng} \mathrm{m}^{-2} \mathrm{~d}^{-1}\end{array}$ & SD Cd \\
\hline $16 / 10 / 07 \rightarrow 30 / 10 / 07$ & 3036 & 143 & 73 & 1 & 4678 & 30 & 810 & 18 & 251 & 7 \\
\hline $30 / 10 / 07 \rightarrow 13 / 10 / 07$ & 2825 & 143 & 57 & 1 & 4742 & 191 & 613 & 9 & 292 & 6 \\
\hline $13 / 11 / 07 \rightarrow 27 / 11 / 07$ & 1351 & 145 & 40 & 1 & 2449 & 43 & 368 & 7 & 977 & 8 \\
\hline $27 / 11 / 07 \rightarrow 11 / 12 / 07$ & 1224 & 143 & 27 & 1 & 2960 & 33 & 359 & 28 & 142 & 11 \\
\hline $11 / 12 / 07 \rightarrow 02 / 01 / 08$ & 1201 & 104 & 26 & 0 & 3414 & 10 & 481 & 33 & 293 & 10 \\
\hline $02 / 01 / 08 \rightarrow 16 / 01 / 08$ & 1297 & 163 & 32 & 1 & 1621 & 31 & 479 & 18 & 203 & 5 \\
\hline $16 / 01 / 08 \rightarrow 30 / 01 / 08$ & 3317 & 164 & 62 & 2 & 6167 & 157 & 552 & 12 & 450 & 10 \\
\hline $30 / 01 / 08 \rightarrow 13 / 02 / 08$ & 1310 & 143 & 27 & 1 & 4027 & 73 & 342 & 10 & 158 & 3 \\
\hline
\end{tabular}

determined at highly industrialized area in Turkey (Izmir) [41, 42].

The high content of $\mathrm{Mn}$ and Fe in deposition fluxes at industrial site and the strong correlation between these pollutants (Pearson's correlation coefficient $=0.95$ ) are in line with results obtained by chemical characterization of atmospheric particulate matter in the same area $[16,20,24]$. As reported in previous papers, $\mathrm{Mn}$ and Fe atmospheric concentrations measured near Taranto industrial area were the highest in Apulia region. Moreover $\mathrm{Mn}$ and Fe were the most significant markers of mineral park emissions within at the steel plant $[16,20,24]$. The impact of the industrial area on two sampling sites can be highlighted by the contributions of each $\mathrm{PAH}$ to the total deposition fluxes. At industrial site, each PAH accounted for similar percentage to the total PAH flux (about 15-20\%), except for DBA which accounted for about $4 \%$ (see Figure 4). On the contrary, the deposition fluxes at the urban background site (Figure 5) were principally due to benzo[ghi]perylene (25\% of the total flux) identified as marker of vehicular traffic emissions [40, 41]. The different percentage compositions obtained in two sites can be due to predominant contribution of the steel plant on the industrial site. This finding was also confirmed by significant correlation among PAHs and metals at the industrial area (Table 5) and no correlation at the urban background site (Table 6). This evidence highlighted that PAHs and metals at the industrial site were emitted from the common source, the steel plant.

The high time-resolved monitoring campaign enabled us to study the impact of meteoclimatic parameters on daily deposition fluxes of PAHs and metals. The PAH fluxes were positively correlated with rainfall during the sampling period, but significant inverse correlation was found with wind speed $[27,43,44]$. In fact the highest $\mathrm{PAH}$ fluxes were registered during the periods characterized by wind calm and/or high rain frequency $(>10 \%)$. As concerns metals, it was found that when wind direction favored the transport of air masses 
TABLE 5: Correlation coefficients among PAHs and metals collected at the industrial site.

\begin{tabular}{|c|c|c|c|c|c|c|c|c|c|c|c|c|}
\hline & $\mathrm{BaA}$ & $\mathrm{BbF}$ & $\mathrm{BkF}$ & $\mathrm{BaP}$ & IP & $\mathrm{BgP}$ & $\mathrm{DBaA}$ & $\mathrm{Fe}$ & $\mathrm{Mn}$ & $\mathrm{Ni}$ & As & $\mathrm{Cd}$ \\
\hline $\mathrm{BaA}$ & 1.00 & 0.88 & 0.95 & 0.72 & 0.89 & 0.94 & 0.85 & 0.66 & 0.67 & 0.73 & 0.34 & 0.83 \\
\hline $\mathrm{BbF}$ & & 1.00 & 0.88 & 0.76 & 0.99 & 0.98 & 0.83 & 0.64 & 0.66 & 0.67 & 0.33 & 0.75 \\
\hline $\mathrm{BkF}$ & & & 1.00 & 0.75 & 0.88 & 0.91 & 0.88 & 0.65 & 0.69 & 0.69 & 0.33 & 0.77 \\
\hline $\mathrm{BaP}$ & & & & 1.00 & 0.71 & 0.76 & 0.49 & 0.73 & 0.79 & 0.69 & 0.57 & 0.88 \\
\hline IP & & & & & 1.00 & 0.99 & 0.86 & 0.65 & 0.65 & 0.69 & 0.34 & 0.75 \\
\hline $\mathrm{BgP}$ & & & & & & 1.00 & 0.88 & 0.70 & 0.71 & 0.75 & 0.37 & 0.81 \\
\hline $\mathrm{DBaA}$ & & & & & & & 1.00 & 0.71 & 0.70 & 0.83 & 0.27 & 0.70 \\
\hline $\mathrm{Fe}$ & & & & & & & & 1.00 & 0.95 & 0.96 & 0.67 & 0.73 \\
\hline $\mathrm{Mn}$ & & & & & & & & & 1.00 & 0.90 & 0.67 & 0.74 \\
\hline $\mathrm{Ni}$ & & & & & & & & & & 1.00 & 0.55 & 0.75 \\
\hline As & & & & & & & & & & & 1.00 & 0.65 \\
\hline $\mathrm{Cd}$ & & & & & & & & & & & & 1.00 \\
\hline
\end{tabular}

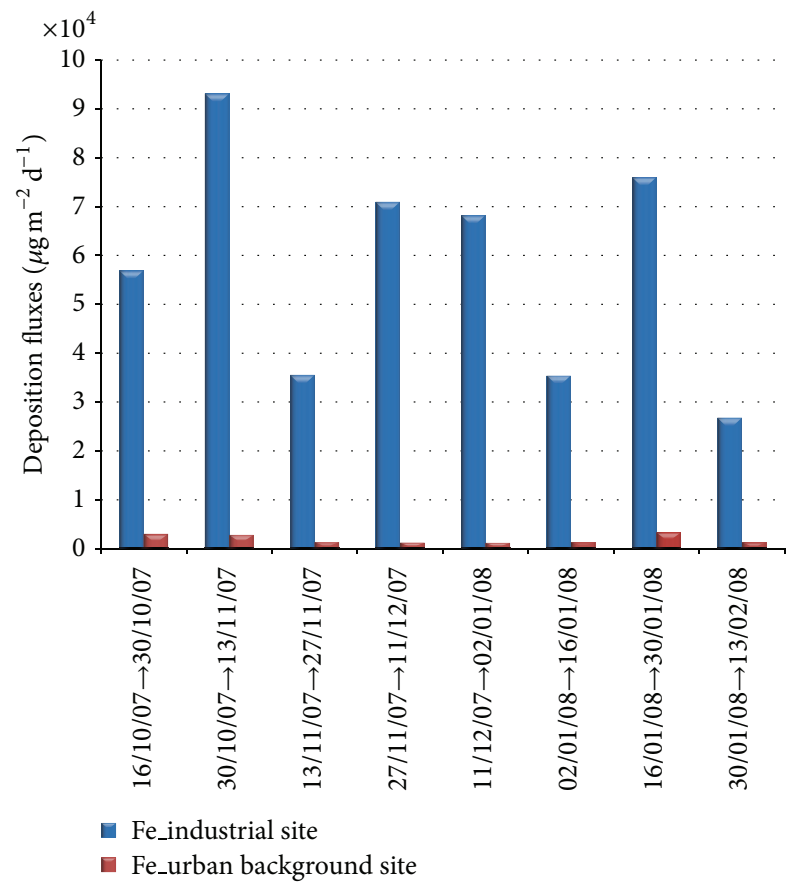

Figure 3: Iron (Fe) deposition fluxes $\left(\mu \mathrm{g} \mathrm{m}^{-2} \mathrm{~d}^{-1}\right)$ at two monitored sites.

from the steel plant to receptor site, the highest Fe and Mn fluxes were detected (Figure 6). Moreover, high fluxes were registered even during calm period. This evidence can be explained considering the proximity of receptor site to the industrial source.

At the end, several diagnostic ratios (IP/(IP $+\mathrm{BgP})$, $\mathrm{IP} / \mathrm{BgP}$, and $\mathrm{BaP} / \mathrm{BgP}$ ) were calculated in order to identify the industrial area as the main emission source. PAH diagnostic ratios have recently come into common use as a tool for identifying and assessing pollution emission sources [17, 28, 45-49]. The use of diagnostic ratios is based on the principle

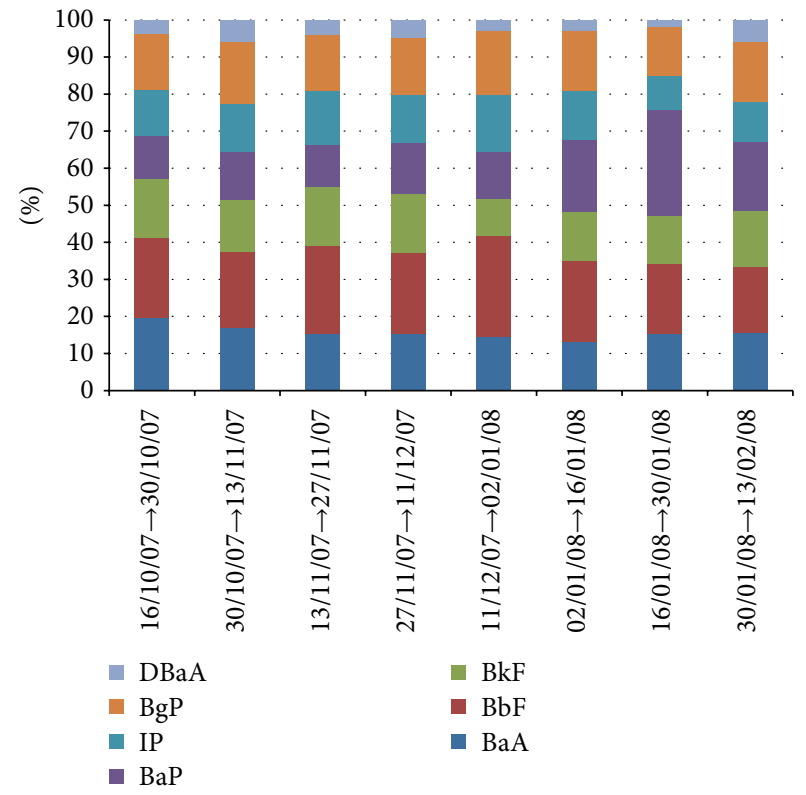

Figure 4: Percentage contributions of each PAH to the total deposition fluxes at the industrial site.

that some PAHs are emitted in reasonably regular proportions and the paired compounds are diluted to a similar extent during transport, and thus their subsequent ratios remain constant between the source and receptor. Diagnostic ratios were used to identify pyrogenic or petrogenic sources, diesel or gasoline emission, fuel or biomass combustion, and traffic related sources [17, 28, 45-49]. Values of IP/(IP $+\mathrm{BgP}), \mathrm{IP} / \mathrm{BgP}$, and $\mathrm{BaP} / \mathrm{BgP}$ were $0.44,0.78$, and 1.13 , respectively, in agreement with those reported in literature for coke combustion emissions [17, 45-50]. Lower diagnostic ratio values were found for urban background site ( 0.60 for all ratios) confirming the combustion processes of gasoline and diesel as the most important source of PAHs in this site $[49,50]$. 
TABLE 6: Correlation coefficients among PAHs and metals collected at the urban background site.

\begin{tabular}{|c|c|c|c|c|c|c|c|c|c|c|c|c|}
\hline & $\mathrm{BaA}$ & $\mathrm{BbF}$ & $\mathrm{BkF}$ & $\mathrm{BaP}$ & IP & $\mathrm{BgP}$ & $\mathrm{DBaA}$ & $\mathrm{Fe}$ & $\mathrm{Mn}$ & $\mathrm{Ni}$ & As & $\mathrm{Cd}$ \\
\hline $\mathrm{BaA}$ & 1.00 & 0.98 & 0.98 & 0.90 & 0.96 & 0.90 & 0.63 & -0.43 & -0.42 & -0.50 & -0.01 & -0.18 \\
\hline $\mathrm{BbF}$ & & 1.00 & 0.94 & 0.92 & 0.96 & 0.91 & 0.66 & -0.35 & -0.33 & -0.45 & 0.11 & -0.31 \\
\hline $\mathrm{BkF}$ & & & 1.00 & 0.85 & 0.91 & 0.82 & 0.48 & -0.53 & -0.50 & -0.57 & -0.11 & -0.07 \\
\hline $\mathrm{BaP}$ & & & & 1.00 & 0.96 & 0.92 & 0.76 & -0.41 & -0.39 & -0.59 & 0.00 & -0.36 \\
\hline IP & & & & & 1.00 & 0.96 & 0.79 & -0.44 & -0.44 & -0.55 & -0.06 & -0.29 \\
\hline $\mathrm{BgP}$ & & & & & & 1.00 & 0.82 & -0.23 & -0.29 & -0.36 & 0.05 & -0.33 \\
\hline $\mathrm{DBaA}$ & & & & & & & 1.00 & -0.11 & -0.11 & -0.40 & 0.13 & -0.33 \\
\hline $\mathrm{Fe}$ & & & & & & & & 1.00 & 0.95 & 0.84 & 0.79 & 0.01 \\
\hline $\mathrm{Mn}$ & & & & & & & & & 1.00 & 0.69 & 0.86 & 0.15 \\
\hline $\mathrm{Ni}$ & & & & & & & & & & 1.00 & 0.51 & -0.10 \\
\hline As & & & & & & & & & & & 1.00 & -0.17 \\
\hline $\mathrm{Cd}$ & & & & & & & & & & & & 1.00 \\
\hline
\end{tabular}

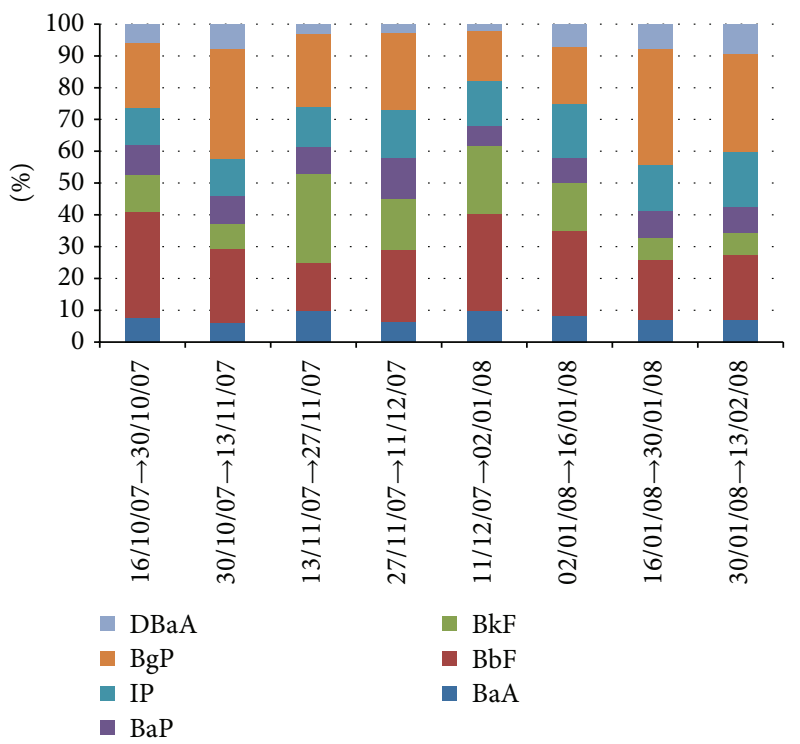

FIgURE 5: Percentage contributions of each PAH to the total deposition fluxes at the urban background site.

\section{Conclusions}

A high time-resolved monitoring campaign of bulk depositions of PAHs and metals was conducted at an industrial site (sampling period of one week) and at an urban site (sampling period of two weeks) in province of Taranto from October 16, 2007, to February 13, 2008. The analysis of deposition fluxes and the study of the impact of meteoclimatic parameters enabled the evaluation of the impact of the biggest European steel plant on the surrounding area. It was found that average deposition fluxes of $\mathrm{BaP}\left(147.6 \mathrm{ng} \mathrm{m}^{-2} \mathrm{~d}^{-1}\right)$, $\mathrm{BaA}\left(162.3 \mathrm{ng} \mathrm{m}^{-2} \mathrm{~d}^{-1}\right)$, and $\mathrm{BkF}\left(140.9 \mathrm{ng} \mathrm{m}^{-2} \mathrm{~d}^{-1}\right)$ at the industrial site were on average 10,14 , and 8 times higher than those detected in urban sites, respectively. The impact of the industrial was also confirmed by diagnostic ratios as $\mathrm{IP} /(\mathrm{IP}+\mathrm{BgP}), \mathrm{IP} / \mathrm{BgP}$, and $\mathrm{BaP} / \mathrm{BgP}$. The same findings were obtained for most metals. The deposition fluxes of $\mathrm{Ni}\left(19.8 \mu \mathrm{g} \mathrm{m}^{-2} \mathrm{~d}^{-1}\right)$, As $\left(2.2 \mu \mathrm{g} \mathrm{m}^{-2} \mathrm{~d}^{-1}\right)$, Fe $\left(57 \mathrm{mg} \mathrm{m}^{-2} \mathrm{~d}^{-1}\right)$,

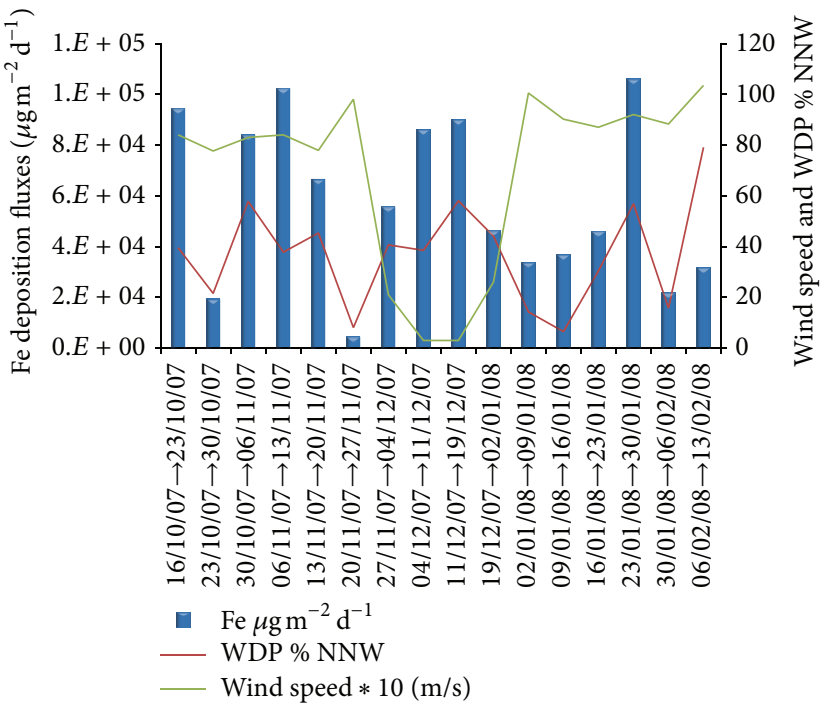

FIgURE 6: Fe deposition fluxes $\left(\mu \mathrm{g} \mathrm{m}^{-2} \mathrm{~d}^{-1}\right)$, wind speed $(\mathrm{m} / \mathrm{sec})$, and probability of wind direction (WDP) from North-North-West $(\mathrm{NNW})$ in percentage at the industrial site.

and $\mathrm{Mn}\left(1.02 \mathrm{mg} \mathrm{m}^{-2} \mathrm{~d}^{-1}\right)$ at industrial site were $6,5,31$, and 31 times higher than those determined at urban site, respectively. Therefore, this work has enabled us to obtain useful information about deposition fluxes of micropollutants near the biggest European steel plant, information not available in the literature up to now.

\section{Conflict of Interests}

The authors declare that there is no conflict of interests regarding the publication of this paper.

\section{References}

[1] C. Venkataraman, G. Habib, A. Eiguren-Fernandez, A. H. Miguel, and S. K. Friedlander, "Residential biofuels in South Asia: carbonaceous aerosol emissions and climate impacts," Science, vol. 307, no. 5714, pp. 1454-1456, 2005. 
[2] C. Chu, G. Fang, J. Chen, and I. Yang, "Dry deposition study by using dry deposition plate and water surface sampler in Shalu, central Taiwan," Environmental Monitoring and Assessment, vol. 146, no. 1-3, pp. 441-451, 2008.

[3] G. Fang, Y. Huang, J. Huang, and C. Liu, "Dry deposition of Mn, $\mathrm{Zn}, \mathrm{Cr}, \mathrm{Cu}$ and $\mathrm{Pb}$ in particles of sizes of $3 \mu \mathrm{m}, 5.6 \mu \mathrm{m}$ and $10 \mu \mathrm{m}$ in central Taiwan," Journal of Hazardous Materials, vol. 203-204, pp. 158-168, 2012.

[4] R. W. Macdonald, T. Harner, and J. Fyfe, "Recent climate change in the Arctic and its impact on contaminant pathways and interpretation of temporal trend data," Science of the Total Environment, vol. 342, no. 1-3, pp. 5-86, 2005.

[5] J. J. Helble, W. Mojtahedi, J. Lyyränen, J. Jokiniemi, and E. Kauppinen, "Trace element partitioning during coal gasification," Fuel, vol. 75, no. 8, pp. 931-939, 1996.

[6] F. E. Huggins, G. P. Huffman, W. P. Linak, and C. A. Miller, "Quantifying hazardous species in particulate matter derived from fossil-fuel combustion," Environmental Science and Technology, vol. 38, no. 6, pp. 1836-1842, 2004.

[7] J. S. Lighty, J. M. Veranth, and A. F. Sarofim, "Combustion aerosols: factors governing their size and composition and implications to human health," Journal of the Air \& Waste Management Association, vol. 50, no. 9, pp. 1565-1618, 2000.

[8] W. P. Linak, "Metal partitioning in combustion," vol. 1, pp. 95$127,2000$.

[9] P. Bruno, M. Caselli, G. de Gennaro, M. de Rienzo, P. Ielpo, and D. Manigrassi, "Collection and analytical characterisation of the atmospheric particulate in the city of Bari," Annali di Chimica, vol. 92, no. 9, pp. 815-824, 2002.

[10] M. Caselli, P. Ielpo, G. de Gennaro, M. de Rienzo, E. Filippo, and D. Manno, "Heavy metals and particulate matter in the atmosphere of Bari-Italy," Journal of Physics IV, vol. 107, pp. 263266, 2003.

[11] L. Pozzoli, S. Gilardoni, M. G. Perrone, G. de Gennaro, M. de Rienzo, and D. Vione, "Polycyclic aromatic hydrocarbons in the atmosphere: monitoring, sources, sinks and fate. I: monitoring and sources," Annali di Chimica, vol. 94, no. 1-2, pp. 17-32, 2004.

[12] D. Vione, S. Barra, G. de Gennaro et al., "Polycyclic aromatic hydrocarbons in the atmosphere: monitoring, sources, sinks and fate. II: sinks and fate," Annali di Chimica, vol. 94, no. 4, pp. 257-268, 2004.

[13] J. Castro-Jiménez, N. Berrojalbiz, J. Wollgast, and J. Dachs, "Polycyclic aromatic hydrocarbons (PAHs) in the Mediterranean Sea: atmospheric occurrence, deposition and decoupling with settling fluxes in the water column," Environmental Pollution, vol. 166, pp. 40-47, 2012.

[14] M. Tobiszewski and J. Namieśnik, "PAH diagnostic ratios for the identification of pollution emission sources," Environmental Pollution, vol. 162, pp. 110-119, 2012.

[15] M. Amodio, P. Bruno, M. Caselli et al., "Chemical characterization of fine particulate matter during peak PM10 episodes in Apulia (South Italy)," Atmospheric Research, vol. 90, no. 2-4, pp. 313-325, 2008.

[16] M. Amodio, E. Andriani, L. Angiuli et al., "Chemical characterization of PM in the Apulia Region: local and longrange transport contributions to particulate matter," Boreal Environment Research, vol. 16, no. 4, pp. 251-261, 2011.

[17] M. Amodio, M. Caselli, G. de Gennaro, and M. Tutino, "Particulate PAHs in two urban areas of Southern Italy: impact of the sources, meteorological and background conditions on air quality," Environmental Research, vol. 109, no. 7, pp. 812-820, 2009.
[18] M. Amodio, E. Andriani, I. Cafagna et al., "A statistical investigation about sources of PM in South Italy," Atmospheric Research, vol. 98, no. 2-4, pp. 207-218, 2010.

[19] M. Amodio, E. Andriani, M. Caselli et al., "Characterization of particulate matter in the Apulia Region (South of Italy): features and critical episodes," Journal of Atmospheric Chemistry, vol. 63, no. 3, pp. 203-220, 2009.

[20] M. Amodio, E. Andriani, P. R. Dambruoso et al., "A monitoring strategy to assess the fugitive emission from a steel plant," Atmospheric Environment, vol. 79, pp. 455-461, 2013.

[21] "UNI EN 15980: 2011. Air quality-Determination of the deposition of benz [a] anthracene, benzo [b] fluoranthene, benzo [j] fluoranthene, benzo [k] fluoranthene, benzo [a] pyrene, dibenz $[\mathrm{a}, \mathrm{h}]$ anthracene and indeno $[1,2,3-\mathrm{cd}]$ pyrene".

[22] UNI EN, "Ambient Air Quality-Standard method for determination of Arsenic," Cadmium, Lead And Nickel in atmospheric deposition, 2010.

[23] P. Bruno, M. Caselli, G. de Gennaro, and M. Tutino, "Determination of polycyclic aromatic hydrocarbons (PAHs) in particulate matter collected with low volume samplers," Talanta, vol. 72, no. 4, pp. 1357-1361, 2007.

[24] WHO, World Health Organization: Air Quality Guidelines for Europe, vol. 91 of WHO Regional Publications, European Series, WHO, Copenhagen, Denmark, 2nd edition, 2000.

[25] F. Esen, S. S. Cindoruk, and Y. Tasdemir, "Bulk deposition of polycyclic aromatic hydrocarbons (PAHs) in an industrial site of Turkey," Environmental Pollution, vol. 152, no. 2, pp. 461-467, 2008.

[26] W. Wang, S. L. Massey Simonich, B. Giri et al., "Spatial distribution and seasonal variation of atmospheric bulk deposition of polycyclic aromatic hydrocarbons in Beijing-Tianjin region, North China," Environmental Pollution, vol. 159, no. 1, pp. 287293, 2011.

[27] J. Li, H. Cheng, G. Zhang, S. Qi, and X. Li, "Polycyclic aromatic hydrocarbon (PAH) deposition to and exchange at the airwater interface of Luhu, an urban lake in Guangzhou, China," Environmental Pollution, vol. 157, no. 1, pp. 273-279, 2009.

[28] M. B. Yunker, R. W. Macdonald, R. Vingarzan, R. H. Mitchell, D. Goyette, and S. Sylvestre, "PAHs in the Fraser River basin: a critical appraisal of PAH ratios as indicators of PAH source and composition," Organic Geochemistry, vol. 33, no. 4, pp. 489-515, 2002.

[29] K. Ravindra, R. Sokhi, and R. van Grieken, "Atmospheric polycyclic aromatic hydrocarbons: source attribution, emission factors and regulation," Atmospheric Environment, vol. 42, no. 13, pp. 2895-2921, 2008.

[30] A. Gambaro, M. Radaelli, R. Piazza et al., "Organic micropollutants in wet and dry depositions in the Venice Lagoon," Chemosphere, vol. 76, no. 8, pp. 1017-1022, 2009.

[31] T. Nielsen, "Traffic contribution of polycyclic aromatic hydrocarbons in the center of a large city," Atmospheric Environment, vol. 30, no. 20, pp. 3481-3490, 1996.

[32] K. F. Ho, S. S. H. Ho, S. C. Lee et al., "Emissions of gas- and particle-phase polycyclic aromatic hydrocarbons (PAHs) in the Shing Mun Tunnel, Hong Kong," Atmospheric Environment, vol. 43, no. 40, pp. 6343-6351, 2009.

[33] F. Amato, M. Pandolfi, M. Viana, X. Querol, A. Alastuey, and T. Moreno, "Spatial and chemical patterns of PM10 in road dust deposited in urban environment," Atmospheric Environment, vol. 43, no. 9, pp. 1650-1659, 2009. 
[34] L. Han, G. Zhuang, S. Cheng, Y. Wang, and J. Li, "Characteristics of re-suspended road dust and its impact on the atmospheric environment in Beijing," Atmospheric Environment, vol. 41, no. 35, pp. 7485-7499, 2007.

[35] P. Zhao, Y. Feng, T. Zhu, and J. Wu, "Characterizations of resuspended dust in six cities of North China," Atmospheric Environment, vol. 40, no. 30, pp. 5807-5814, 2006.

[36] M. Sakata, Y. Tani, and T. Takagi, "Wet and dry deposition fluxes of trace elements in Tokyo Bay," Atmospheric Environment, vol. 42, no. 23, pp. 5913-5922, 2008.

[37] A. Motelay-Massei, D. Ollivon, K. Tiphagne, and B. Garban, "Atmospheric bulk deposition of trace metals to the Seine river Basin, France: concentrations, sources and evolution from 1988 to 2001 in Paris," Water, Air, and Soil Pollution, vol. 164, no. 1-4, pp. 119-135, 2005.

[38] C. S. C. Wong, X. D. Li, G. Zhang, S. H. Qi, and X. Z. Peng, "Atmospheric deposition of heavy metals in the Pearl River Delta, China," Atmospheric Environment, vol. 37, no. 6, pp. 767776, 2003.

[39] A. Soriano, S. Pallarés, F. Pardo, A. B. Vicente, T. Sanfeliu, and J. Bech, "Deposition of heavy metals from particulate settleable matter in soils of an industrialised area," Journal of Geochemical Exploration, vol. 113, pp. 36-44, 2012.

[40] C. W. Sweet, A. Weiss, and S. J. Vermette, "Atmospheric deposition of trace metals at three sites near the great lakes," Water, Air, \& Soil Pollution, vol. 103, no. 1-4, pp. 423-439, 1998.

[41] B. Herut, M. Nimmo, A. Medway, R. Chester, and M. D. Krom, "Dry atmospheric inputs of trace metals at the Mediterranean coast of Israel (SE Mediterranean): sources and fluxes," Atmospheric Environment, vol. 35, no. 4, pp. 803-813, 2001.

[42] M. Odabasi, A. Muezzinoglu, and A. Bozlaker, "Ambient concentrations and dry deposition fluxes of trace elements in Izmir, Turkey," Atmospheric Environment, vol. 36, no. 38, pp. 58415851, 2002.

[43] T. Gocht, O. Klemm, and P. Grathwohl, "Long-term atmospheric bulk deposition of polycyclic aromatic hydrocarbons (PAHs) in rural areas of Southern Germany," Atmospheric Environment, vol. 41, no. 6, pp. 1315-1327, 2007.

[44] B. Pekey, D. Karakaş, and S. Ayberk, "Atmospheric deposition of polycyclic aromatic hydrocarbons to Izmit Bay, Turkey," Chemosphere, vol. 67, no. 3, pp. 537-547, 2007.

[45] K. Ravindra, L. Bencs, E. Wauters et al., "Seasonal and sitespecific variation in vapour and aerosol phase PAHs over Flanders (Belgium) and their relation with anthropogenic activities," Atmospheric Environment, vol. 40, no. 4, pp. 771-785, 2006.

[46] K. Ravindra, E. Wauters, S. K. Tyagi, S. Mor, and R. van Grieken, "Assessment of air quality after the implementation of compressed natural gas (CNG) as fuel in public transport in Delhi, India," Environmental Monitoring and Assessment, vol. 115, no. 1-3, pp. 405-417, 2006.

[47] I. G. Kavouras, P. Koutrakis, M. Tsapakis et al., "Source apportionment of urban particulate aliphatic and polynuclear aromatic hydrocarbons (PAHs) using multivariate methods," Environmental Science and Technology, vol. 35, no. 11, pp. 22882294, 2001.

[48] S. S. Park, Y. J. Kim, and C. H. Kang, "Atmospheric polycyclic aromatic hydrocarbons in Seoul, Korea," Atmospheric Environment, vol. 36, no. 17, pp. 2917-2924, 2002.

[49] R. M. Dickhut, E. A. Canuel, K. E. Gustafson et al., "Automotive sources of carcinogenic polycyclic aromatic hydrocarbons associated with particulate matter in the Chesapeake Bay region,"
Environmental Science and Technology, vol. 34, no. 21, pp. 46354640, 2000.

[50] R. M. Cavalcante, F. W. Sousa, R. F. Nascimento, E. R. Silveira, and R. B. Viana, "Influence of urban activities on polycyclic aromatic hydrocarbons in precipitation: distribution, sources and depositional flux in a developing metropolis, Fortaleza, Brazil," Science of the Total Environment, vol. 414, pp. 287-292, 2012. 

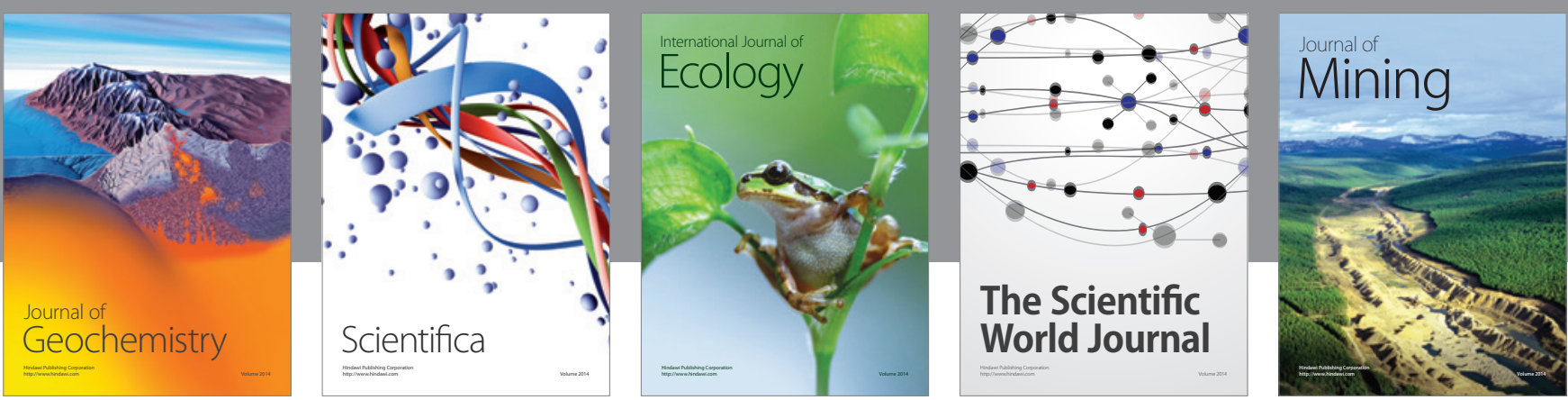

The Scientific World Journal
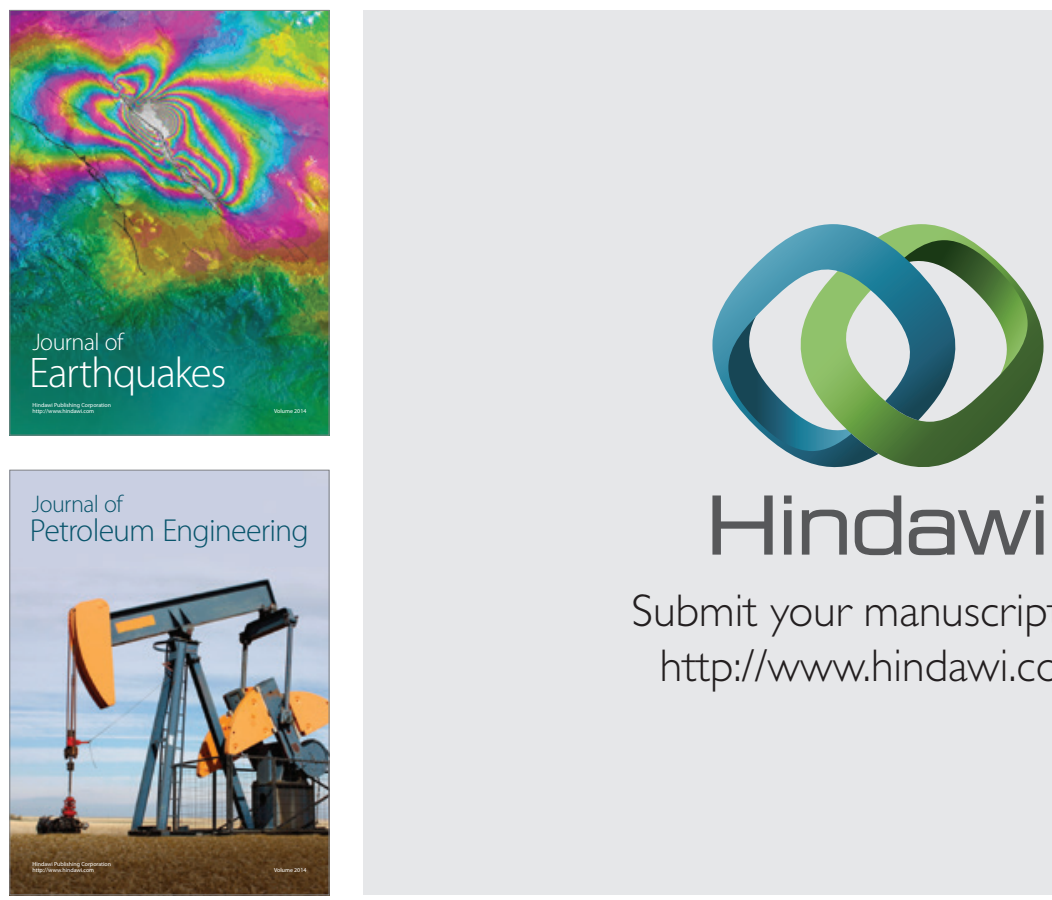

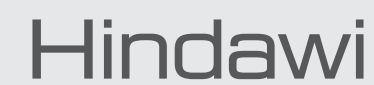

Submit your manuscripts at

http://www.hindawi.com
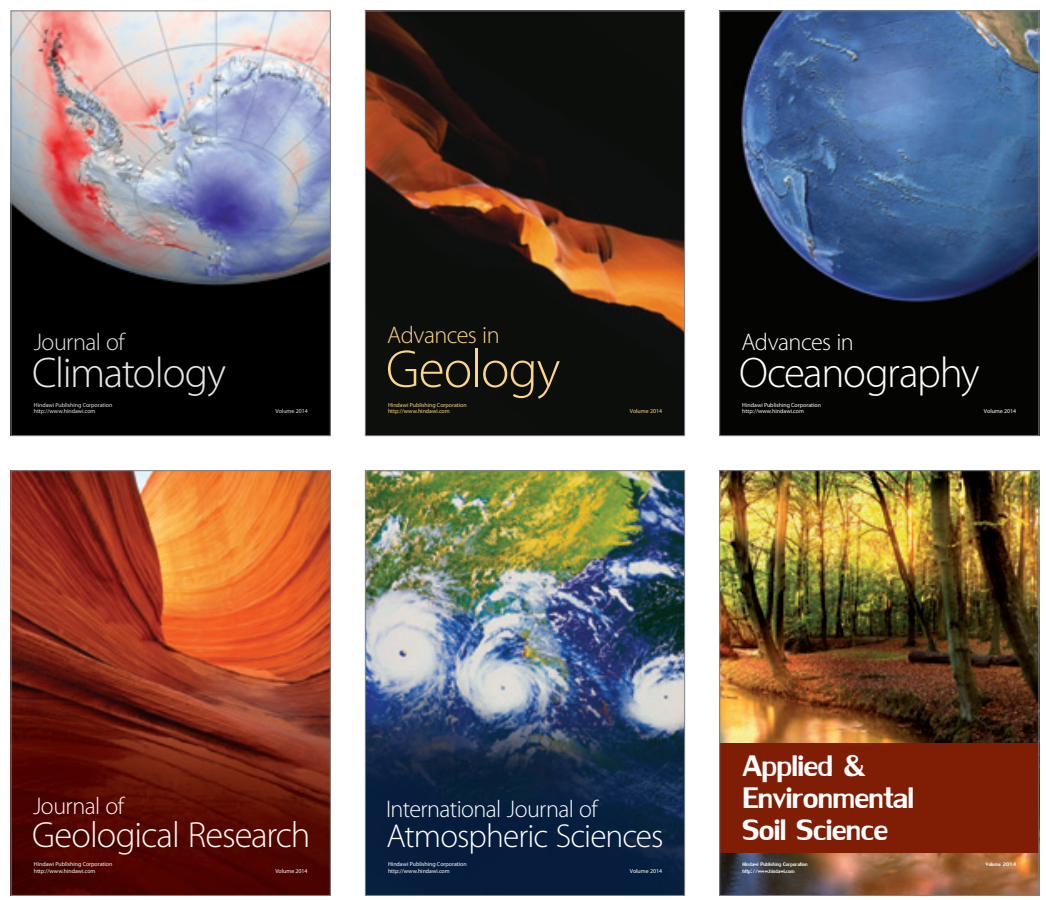
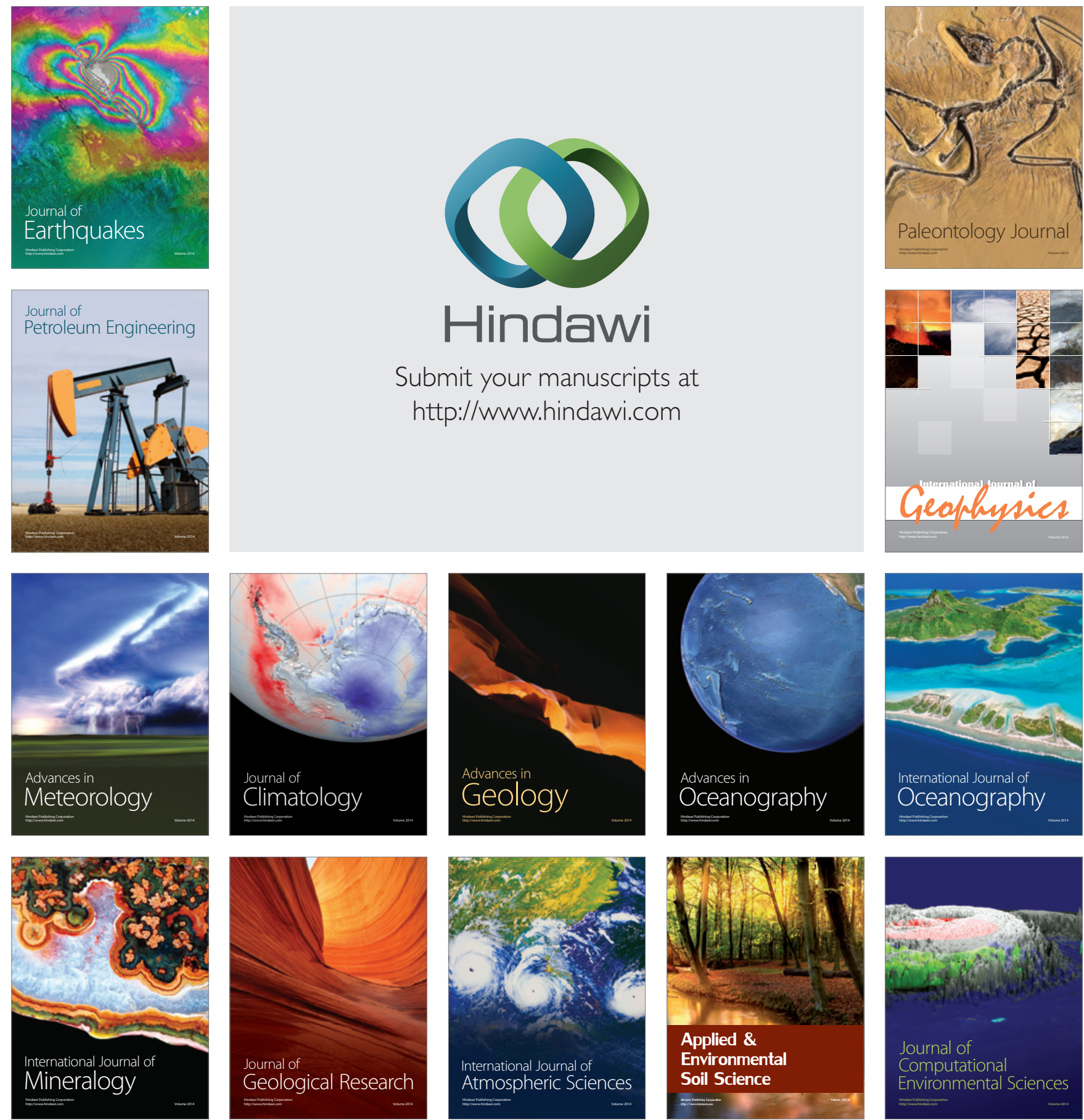